\title{
Digital Preservation of Intangible Cultural Heritage
}

\author{
Wan Malini Wan Isa', Nor Azan Mat Zin², Fadhilah Rosdi ${ }^{3}$, Hafiz Mohd Sarim ${ }^{4}$ \\ ${ }^{1,2,3,4}$ Center for Software Technology and Management (SOFTAM), Faculty of Information Science and Technology, \\ Universiti Kebangsaan Malaysia, Malaysia \\ ${ }^{1}$ Faculty of Informatics and Computing, Universiti Sultan Zainal Abidin, Terengganu, Malaysia
}

\begin{tabular}{l}
\hline \hline Article Info \\
\hline Article history: \\
Received Aug 28, 2018 \\
Revised Oct 20, 2018 \\
Accepted Oct 29, 2018 \\
\hline Keywords: \\
Cultural Heritage Preservation \\
Digital Preservation \\
Intangible Cultural Heritage \\
Tangible Cultural Heritage
\end{tabular}

1. INTRODUCTION

Tremendous growth of technology in recent years indicates their relevance to our everyday life and this development has contributed to the increasing number of digital preservation efforts in heritage domain. Cultural heritage domain substantially uses digital preservation technologies to preserve knowledge, collection of manuscripts and artefacts [1]. Cultural heritage is a symbol of spiritual and intellectual wealth of all civilizations [2]. It is an important representation of a society and nation, besides reflecting a person's identity. The word 'culture' is a reflection of the beliefs, values and norms of a society, providing a connection between the past, present and the future [3], [4]. While heritage can be defined as a valuable thing inherited from previous generations and what will be inherited by the future generations [3], [5]. Moreover, heritage is one of the key components that play an important role to create character, identity and national image [6].

Preservation is an action that preserves cultural heritage and historical objects [7]. According to the United Nations Educational, Scientific and Cultural Organizations (UNESCO), the original condition of these objects must be maintained unchanged [8]. Physical preservation can be carried out by conservation, and restoration, while knowledge and information of cultural heritage can be preserved digitally. Therefore, cultural heritage preservation is important for four reasons; cultural memory, convenient proximity, environment diversity and economic gain [1].

The rapid development and past colonialization may cause Malaysian cultural heritage to be at risk especially when the important artifacts are not digitally preserved [3]. Globalization and social changes are also becoming threats to the preservation of cultural heritage since these elements cause the current younger generation to be disinterested in learning about the knowledge and their cultural heritage. In addition, the 
younger generation has low level of heritage awareness and are reluctant to engage in cultural heritage conservation programs [9], [10]. In order to preserve the cultural heritage, especially the intangible cultural heritage, some efforts are needed to digitize the cultural heritage so that it will not disappear or become extinct. However, some improvements can be made, especially in digital preservation methods for intangible cultural heritage [11].

This paper presents an analysis of cultural heritage awareness among the Malaysians, the current preservation methods and the need for digital preservation for intangible cultural heritage from the experts' perspectives. The remaining paper is organized as follows: Section 2 discusses the background and related work on cultural heritage and their preservation; Section 3 describes the method of this study; Section 4 presents the results and discussion and Section 5 present the conclusion.

\section{BACKGROUND AND RELATED WORK}

\subsection{Cultural Heritage}

Heritage can be described as elements of the past that are valuable and has been passed down from generation to the next generation [12], [3], [5]. In addition, heritage can also be defined as knowledge and expertise inherited through the way of life and belief, and described the overall memory of the community and symbolized the civilization of a society [13]. Moreover, it is a treasure that has been or is being owned by a person or a group of society or people who collectively shared responsibilities for protection and retention of that treasure. Culture is a term that defines the way of life, thoughts and behaviors of a civilization that are inherited from one generation to another and furthermore some experts have explained that a culture is the value in humans that helps to create and build identity [14]. Additionally, culture can be a reflection of knowledge, laws, beliefs, morals, customs, art or any other habits and capabilities required by human beings in the community [15], [16].

To summarize, cultural heritage can be depicted as the legacy of physical artefacts and intangible attributes of a group or society that are inherited from the past generations, maintained in the present and presented for the benefit of future generations [17]. Generally, cultural heritage can be divided into two categories as shown in Figure 1, tangible cultural heritage and intangible cultural heritage [18], [19]. The detailed explanation of these categories is discussed in the next section.

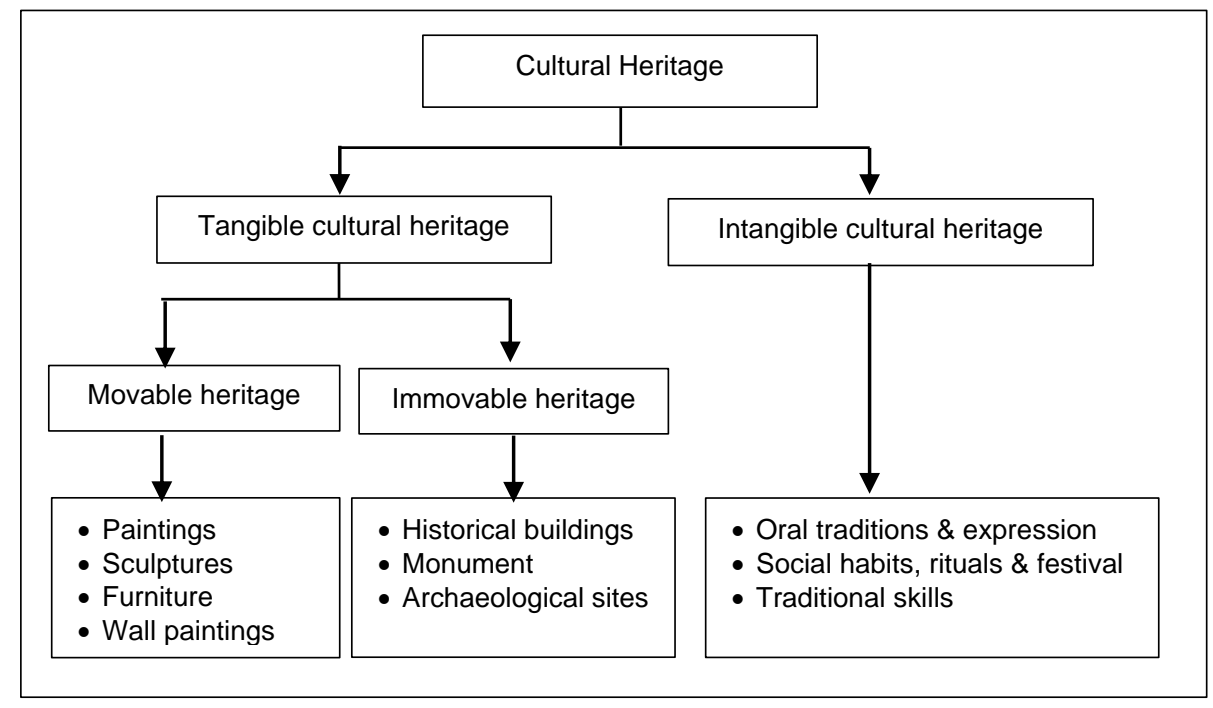

Figure 1. Cultural Heritage Classification from UNESCO [21]

\subsubsection{Tangible Cultural Heritage}

Tangible cultural heritage is a heritage that can to be seen and touched. It includes buildings and historical sites, monuments, artefacts, and others, which are considered important and valuable to be maintained for the future. Furthermore, tangible cultural heritage also comprises the material remains of human activities, works, developments and achievements such as cities and towns, palaces, villages, temples, mausoleums and manufacturing plants [20]. Tangible cultural heritage can be divided into immovable heritage 
and movable heritage as shown in Figure 1 [21]. Immovable heritage includes historical building, monument, archaeological sites meanwhile movable heritage includes paintings, sculptures, furniture and wall paintings which are is usually displayed in museums or stored in archives or research centers.

\subsubsection{Intangible Cultural Heritage}

Intangible cultural heritage involves the oral traditions and expressions, including language; performing arts, social habits, rituals, and festivals; science and habits related to nature and world; and traditional skills [21]. Intangible cultural heritage also contains human act or motion that can be seen, touched, perceived, inhaled, or heard when it was done or existed, but can no longer be enjoyed when it does not exist or end [22]. Furthermore, the Cultural Heritage Convention defines intangible cultural heritage as the practices, representations, expressions, knowledge, skills as well as the instruments, objects, artefacts and cultural spaces associated therewith that communities, groups and, in some cases, individuals recognize as part of their cultural heritage. In addition, this intangible cultural heritage, transmitted from generation to generation, is constantly recreated by communities and groups in response to their environment, their interaction with nature and their history, and provides them with a sense of identity and continuity, thus promoting respect for cultural diversity and human creativity [18].

In 2003, UNESCO has categorized intangible cultural heritage into five domains, namely oral traditions and expressions that include language; performing arts; social practices, rituals and festive events; knowledge and practices concerning nature and the universe and traditional craftsmanship. The explanation of every domains is shown in Table 1.

Table 1. Explanation on intangible cultural heritage domain [21]

\begin{tabular}{ll}
\hline \multicolumn{1}{c}{ Domain } & \multicolumn{1}{c}{ Explanation } \\
\hline Oral traditions and expression & $\begin{array}{l}\text { An enormous variety of spoken forms including } \\
\text { proverbs, riddles, tales, nursery rhymes, legends, } \\
\text { myths, epic songs and poems, charms, prayers, chants, } \\
\text { songs, dramatic performances and more }\end{array}$ \\
& $\begin{array}{l}\text { Range from vocal and instrumental music, dance and } \\
\text { theatre to pantomime, sung verse and beyond. }\end{array}$ \\
Performing arts & $\begin{array}{l}\text { Habitual activities that structure the lives of } \\
\text { communities and groups and that are shared by and } \\
\text { relevant to many of their members. }\end{array}$ \\
Kocial practices, rituals and festive events & $\begin{array}{l}\text { knowledge, knowhow, skills, practices and } \\
\text { representations developed by communities by } \\
\text { interacting with the natural environment. }\end{array}$ \\
Traditional craftsmanship & $\begin{array}{l}\text { Skills and knowledge involved in craftsmanship rather } \\
\text { than the craft products themselves }\end{array}$ \\
\hline
\end{tabular}

Intangible cultural heritage is important in maintaining the cultural diversity in the face of a growing globalization. Understanding of intangible cultural heritage among different communities would encourage mutual respect for the way a community lives, so in order to sustain this intangible cultural heritage for the future, preservation should be carried out diligently.

\subsection{Cultural Heritage Preservation}

An action that preserves cultural heritage objects and historical objects can be defined as preservation [7]. Preservation is an act or process to take action to defend the existing form, integrity and material of a building or structure and protective plant of a site [23]. Moreover, Malaysia National Heritage Act, 2005 (Act 645) also has stated that preservation is an act that aims to stop further deterioration, decay or obsolete conditions of buildings, monuments and sites.

There are four major importance of cultural heritage preservation-for cultural memory, distance facilities, environmental diversity and economic benefits [1]. Heritage element plays an important role in cultural memorial as the preservation of cultural heritage can preserve physical material in physical form and can transfer the valuable knowledge and skills from the previous generation to the present and future generations. Furthermore, the preservation of cultural heritage can support the interaction between environments, humans and community activities. The diversity of the environment as the identity of the local community and the preservation of cultural heritage will retain local artefacts and local artisans in line with the development of a society. In term of economic profitability, preservation can benefit the community in two ways such as saving costs in terms of constructing new buildings and becoming tourist attractions. Furthermore, 
cultural heritage preservation can contribute to other aspects of life, such as tourism, content industry, security and defense, and business [7].

Currently, the world cultural heritage is threatened by the development of urban culture, rapid pace of life, technological and economic growth [24], [25]. This situation causes the younger generation to have low level of awareness about their own heritage and they seem disinterested in learning about the knowledge concerning preservation of cultural heritage. Several efforts have been carried out by certain agencies such as UNESCO, to encourage preservation of heritage in society. One of the efforts undertaken by UNESCO was the launch of the "Memory of the World" program in 1992. Among the objectives of the program were to promote the preservation of world heritage, to help regional access to legacy documentaries through traditional methods and digital technology, and to raise awareness about the existence and importance of legacy documentaries.

In Malaysia, the government has established a Department of National Heritage (Jabatan Warisan Negara) in 2006, as one of the efforts toward heritage preservation. This department is responsible for conserving, preserving, protecting and promoting the heritage in Malaysia. Moreover, through this department, National Heritage Act (Act 645) was introduced, the main objective is to focus on the preservation of national heritage, tangible cultural heritage, intangible cultural heritage and natural heritage. The act also provides the basic rules and regulations pertaining the protection and management of heritage treasures besides establishing a National Heritage List. Malaysia also support this effort by focusing more on preserving and conserving tangible and intangible cultural heritage products through the Ninth Malaysia Plan (RMK 9).

\subsection{Intangible cultural heritage preservation}

Currently, the efforts to preserve and safeguard cultural heritage do not only focus on physical objects such as buildings and their surroundings, but include intangible cultural heritage, such as language, art, and customs [26]. However, a different approach is needed for intangible cultural heritage preservation, based on recommendations by UNESCO which stressed the necessity to involve the community performers' to protect their traditions [27]. In the 2003 convention, UNESCO has set a list of guidelines or regulations for the protection of intangible cultural heritage. The guidelines aim to protect the use, representation, expression, knowledge and technique that communities, groups and individuals recognize as part of their cultural heritage. Moreover, the main intellectual and operational steps to be followed by a government of a country and in the international level to protect intangible cultural heritage are also introduced during the convention.

In addition, UNESCO has started several projects related to the protection of intangible cultural heritage [28]. The most prominent ones are the establishment of two lists that have been released in the 2003 Convention on the List of Intangible Cultural Heritage International Lists and Intangible Cultural Heritage List which require immediate protection. The lists include an international inventory of traditional expressions and they can be accessed online, including the photographs and audio-visual recordings of cultural expressions. The inventory acts as an archive source that raises awareness of traditional expressions in a community. However, the weakness of this lists is that they only aim to promote rather than to create activities that have direct impact on the local community [29].

The rapid development of technology has initiated new initiatives to preserve intangible cultural heritage. Digital preservation is one of the technological approach that can be used for preservation of intangible culture heritage. It is not only a way of preserving our cultural heritage but it also provides an easy tool to archive the material as references for education purposes, especially for the future generation [2]. Moreover, the act of preserving and archiving are able to sustain the digitized resources [16].

One of the digital preservation was carried out by the Centre for Traditional Arts \& Ethnology in Luang Prabang, Laos. As the preservation method, they have recorded audio and video of the Iu Mien New Year celebration using high definition digital audio and video. The authors mentioned that the concern is when older generations disappear, the cultural traditions and rituals associated with this feast may be lost forever. Therefore, digitalization of intangible cultural heritage, through digital media and mobile technology can potentially preserve them for the future generations [30].

More efforts are required for digital preservation. Studies from Hu, Lv and Zhang [11] concurred that digital preservation for intangible cultural heritage are still needed. Digitalization of intangible cultural heritage knowledge should be made to retain the knowledge and skills of intangible cultural heritage in a lasting and systematic form. It is important to ensure the continuity of this legacy for the future generations. The remaining sections present a study on the current preservation methods of intangible cultural heritage in Malaysia and the need for digital preservation from expert's perspective. 


\section{METHOD}

A survey using an interview method is used to gather the data in this study. The objectives of the study are to identify the level of cultural heritage awareness, the current preservation method and the need for digital preservation of intangible cultural heritage from the experts' perspectives. There are three phases involved in this study which are setup, data collection and data analysis.

In setup phase, the objectives of the study were identified and the questions for the interview were constructed based on literature. The questions were divided into three sections which are Section A: Demographics, Section B: Experience in cultural heritage domain and Section C: Cultural heritage documentation. Informants are also identified; they are five experts in cultural heritage; an officer of the Department of National Heritage, Perbadanan Kemajuan Kraftangan Malaysia, Lembaga Muzium Negeri Terengganu and two craftsmen. They have at least 8 years' experience in cultural heritage domain.

Next, data collection was carried out using semi structured interview. The interviewer asked the informants to answer the questions in the interview schedule and in addition, asked further probing questions based on informants' feedback to get further information. Each interview session was recorded to facilitate data analysis process. The last step was analyzing answers from the interview. The obtained data were analyzed using thematic analysis techniques to identify, analyze and report according to the themes.

\section{RESULT AND DISCUSSION}

In this section, we discuss the results based on the findings from the interviews.

\subsection{Findings on cultural heritage awareness}

The results on the cultural heritage awareness showed that most of the informants (80\%) believed that the level of community awareness is low, as shown in Figure 2. The people are still not aware of the importance of preserving the heritage, especially the intangible cultural heritage. They also implied that the community is not interested in knowing and preserving the heritage even though there have been suggestions from the leaders to preserve the heritage, and many research articles have been published regarding the importance of this issue. If this situation remained unchanged, the heritage can be lost. However, various efforts have been made to raise public awareness, such as workshop-development programs and forums, organizing exhibitions in a nationwide promotion and creating a live museum. In addition, educational promotions such as awareness programs in primary and secondary schools as well as short and long term training are also held.

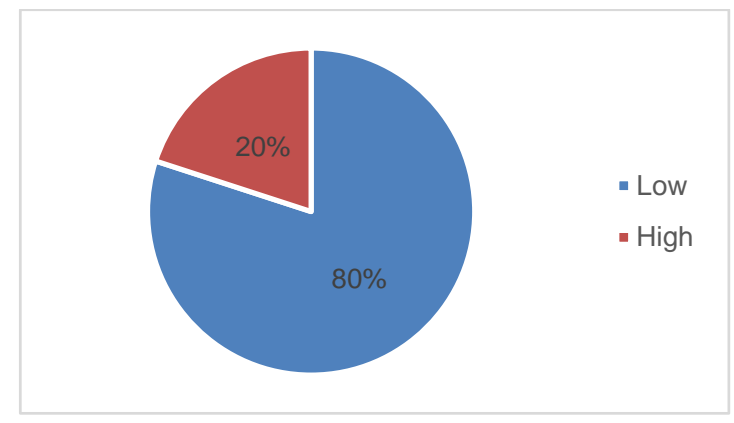

Figure 2. Level of cultural heritage awareness

\subsection{Findings on intangible cultural heritage preservation method}

The findings from the interview showed that the practitioners of intangible cultural heritage such as craftsmen, transferred their knowledge by oral and practical methods, the same way they inherited their knowledge from previous generation. The four informants stated that no documentation was recorded during the knowledge transfer process thus the knowledge remain undocumented and unpreserved. Moreover, all the informants, as shown in Figure 3 concluded that presently the practitioners of intangible cultural heritage stored their knowledge in their memory, without specific preservation method to retain the knowledge. These practices show that the heritage knowledge and skills solely depend on each practitioner, without any standard or agreed method among them. 


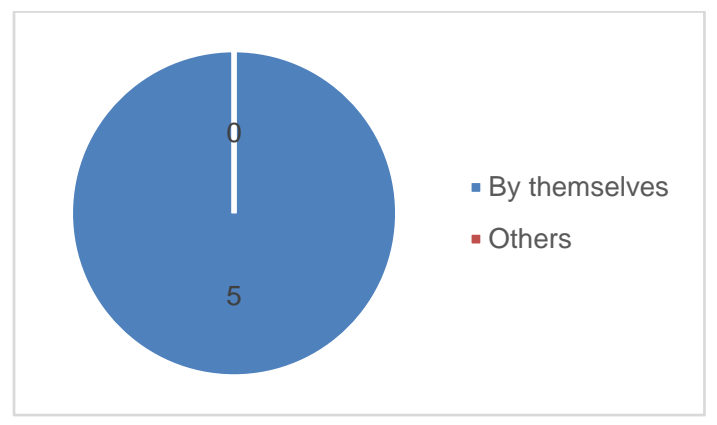

Figure 3. Current preservation method of intangible cultural heritage

\subsection{Findings on the need for digital preservation}

All informants in Figure 4, recognized the need to digitize the heritage knowledge and skills so that it can be stored permanently for preservation and safeguard. While there are some efforts to keep this cultural heritage knowledge in the form of repositories in some government agencies but it is only for internal use. The public cannot access the repository to get more information about cultural heritage. This requires more effort to preserve the heritage so that it can be accessed by the public to increase their awareness and to ensure the information does not become extinct and can be protected for the future generations.

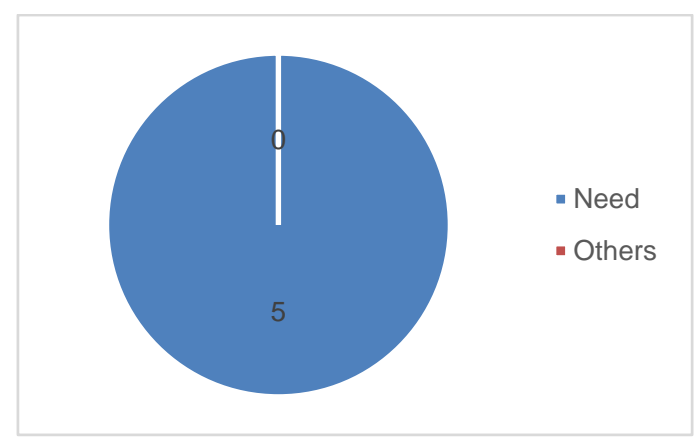

Figure 4. The need of digitalization of intangible cultural heritage knowledge

\section{CONCLUSION}

Cultural heritage is important to be preserved and protected for the future generation. Heritage reflect a community's identity, therefore they must be preserved. Apart from preservation of tangible heritage, intangible cultural heritage is also an important domain that needed preservation. In digital technology era, digital preservation is one of the methods to protect this valuable heritage. However, lack of digital preservation of the intangible cultural heritage requires more efforts to be made to prevent the heritage from disappearing and becoming extinct.

This paper has discussed on heritage and presented results from the preliminary study on issues of intangible cultural heritage, specifically the need for more efforts to preserve it. There is a low level of awareness in preserving intangible cultural heritage among the society and presently the practitioners of heritage keep the knowledge in their memory as a preservation method. However, they are aware of the need to preserve the knowledge and skills digitally. Therefore, digital preservation is significant to be used for intangible cultural heritage knowledge as a preservation method. Future study will look into best approaches to preserve intangible heritage of local craft.

\section{ACKNOWLEDGMENT}

The author would like to acknowledge Universiti Kebangsaan Malaysia for funding this research under the Grand Challenge Fund (DCP-2017-007/2). We also thank the Skim Latihan Akademik (SLAB)/ Skim Latihan Akademik IPTA (SLAI), Ministry of Higher Education of Malaysia. 


\section{REFERENCES}

[1] S. Prompayuk and P. Chairattananon. Preservation of Cultural Heritage Community: Cases of Thailand and Developed Countries. Procedia-Social and Behavioral Sciences. 2016; 234: 239-243.

[2] M. Z. Idris, N. B. Mustaffa, and S. O. Syed Yusoff. Preservation of Intangible Cultural Heritage Using Advance Digital Technology: Issues and Challenges. Harmonia: Journal of Arts Research \& Education. 2016; 16(1): 1-13.

[3] Z. Abd Manaf and A. Ismail. Malaysian cultural heritage at risk?: A case study of digitisation projects. Library. Review. 2010; 59(2): 107-116.

[4] C. L. Liew. Online cultural heritage exhibitions: A survey of information retrieval features. Electronic Library Information System. 2005; 39(1): 4-24.

[5] UNESCO, Operational Guidelines for the Implementation of the World Heritage Convention. Paris: UNESCO World Heritage Centre, 2015.

[6] T. Petronela. The Importance of the Intangible Cultural Heritage in the Economy. Procedia Economics and Finance. 2016; 39: 731-736.

[7] H. Kurniawan, A. Salim, H. Suhartanto, and Z. A. Hasibuan. E-Cultural Heritage and Natural History Framework: an integrated approach to digital preservation. International Conference on Telecommunication Technology and Applications (IACSIT). Singapore. 2011: 177-182

[8] I. S. Division. Guidelines for the Preservation of Digital Heritage. National Library of Australia. 2003.

[9] N. Azman, S. A. Halim, O. P. Liu, S. Saidin, and I. Komoo. Public education in heritage conservation for geopark community. Procedia-Social and Behavioral Sciences. 2010; 7: 504-511.

[10] M. Jaafar, S. M. Noor, and S. M. Rasoolimanesh. Awareness and willingness for engagement of youth on world heritage site: A study on lenggong archaeological site. Asian Social Science. 2014; 10(22): 29-36.

[11] J. Hu, Y. Lv, and M. Zhang. The Ontology Design of Intangible Cultural Heritage Based on CIDOC CRM. International Journal of u-and e-Service, Science and Technology. 2014; 7(1): 261-274.

[12] S. M. Noor, K. Y. Lim, and R. Mohamed. Building Lenggong World Heritage Site Brand Identity: Assessing Core Values Of Local Community. International Conference on Tourism Development. Penang. 2013: 220-231.

[13] Jabatan Warisan Negara, "Jabatan Warisan Negara: Soalan Lazim," 2016. [Online]. Available: http://www.heritage.gov.my/ms/kenali-kami/soalan-lazim.

[14] F. Matarasso. Recognising Culture-A series of briefing papers on culture and development. London: Canadian Heritage. 2001.

[15] E. B. Tylor. Primitive Culture: Researches Into The Development. London: John Murray, 1871.

[16] Z. Abd Manaf. The state of digitisation initiatives by cultural institutions in Malaysia: An exploratory survey. Library Review. 2007; 56(1): 45-60.

[17] UNESCO, "Tangible Cultural Heritage," 2017. [Online]. Available: http://www.unesco.org/new/en/cairo/culture/tangible-cultural-heritage/. [Accessed: 16-Apr-2018].

[18] UNESCO, "Convention for the Safeguarding of the Intangible Cultural Heritage," 2003.

[19] M. Y. Yuszaidy, D. Hanapi, K. Ab Samad, and O. D. Mohamed Anwar. Pembangunan Warisan di Malaysia: Tinjauan Umum Tentang Dasar. Jurnal Melayu. 2010; 5: 277-283.

[20] S. Hua. World heritage classification and related issues - A case study of the 'Convention concerning the protection of the world cultural and natural heritage. Procedia-Social and Behavioral Sciences. 2010; 2(5): 6954-6961.

[21] UNESCO, "Intangible Heritage domains in the 2003 Convention." [Online]. Available: https://ich.unesco.org/en/1com. [Accessed: 12-Oct-2016].

[22] Jabatan Warisan Negara, "Warisan Tidak Ketara: Pengenalan," 2016. [Online]. Available: http://www.heritage.gov.my/ms/warisan-tidak-ketara/grp-warisan-tidak-ketara-pengenalan. [Accessed: 23-Sep2017].

[23] E. L. Howe, B. J., Fleming, D. A., \& Kemp. Houses and Homes: Exploring Their History, Vol 2. Walnut Creek: Rowman Altamira, 1997.

[24] M. Alivizatou. Intangible Heritage and Erasure: Rethinking Cultural Preservation and Contemporary Museum Practice. International Journal of Cultural Property. 2011; 18(1): 37-60.

[25] Loh G. S. Consumption Patterns and Retail Activities in George Town. Penang. Universiti Sains Malaysia, 2001.

[26] I. Syahrul, M. Radzuan, N. Fukami, and Y. Ahmad. Cultural heritage, incentives system and the sustainable community: Lessons from Ogimachi Village, Japan. Geografia. Malaysian Journal of Society and Space. 2014; 10(1): 130-146.

[27] M. Severo and T. Venturini. Intangible cultural heritage webs: Comparing national networks with digital methods. New Media \& Society. 2016; 18(8): 1616-1635.

[28] N. Aikawa. An Historical Overview of the Preparation of the UNESCO International Convention for the Safeguarding of the Intangible Cultural Heritage. Museum International. 2014; 56(1-2): 137-149.

[29] Hafstein, V., Intangible Heritage as List: From Masterpieces to Representation. In: Smith L. and Akagawa N. Intangible Heritage. Abingdon: Routledge. 2009: 93-111.

[30] K. Papangelis, A. Chamberlain, and H.-N. Liang. New directions for preserving intangible cultural heritage through the use of mobile technologies. Proceedings of the 18th International Conference on Human-Computer Interaction with Mobile Devices and Services Adjunct. Florence. 2016; 964-967. 